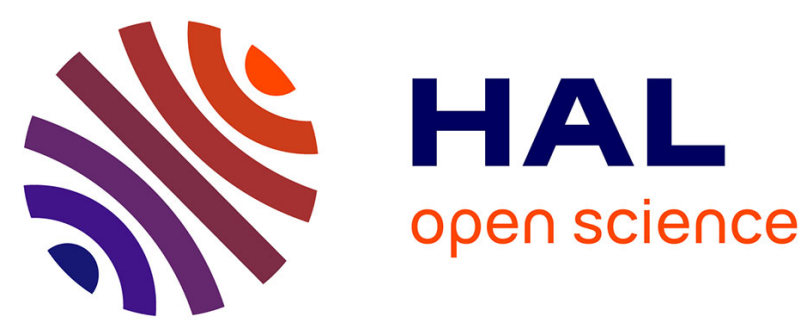

\title{
INFLUENCE OF MAGNETIC LOSSES ON MAXIMUM POWER LIMITS OF SYNCHRONOUS PERMANENT MAGNET DRIVES IN FLUX-WEAKENING MODE
}

\author{
Emmanuel Hoang, Mohamed Gabsi, Michel Lécrivain, Bernard Multon
}

\section{To cite this version:}

Emmanuel Hoang, Mohamed Gabsi, Michel Lécrivain, Bernard Multon. INFLUENCE OF MAGNETIC LOSSES ON MAXIMUM POWER LIMITS OF SYNCHRONOUS PERMANENT MAGNET DRIVES IN FLUX-WEAKENING MODE. IAS 2000 - Roma - Italia, Oct 2000, Roma, Italy. hal-00533008

\section{HAL Id: hal-00533008 https://hal.science/hal-00533008}

Submitted on 4 Nov 2010

HAL is a multi-disciplinary open access archive for the deposit and dissemination of scientific research documents, whether they are published or not. The documents may come from teaching and research institutions in France or abroad, or from public or private research centers.
L'archive ouverte pluridisciplinaire HAL, est destinée au dépôt et à la diffusion de documents scientifiques de niveau recherche, publiés ou non, émanant des établissements d'enseignement et de recherche français ou étrangers, des laboratoires publics ou privés. 


\title{
INFLUENCE OF MAGNETIC LOSSES ON MAXIMUM POWER LiMITS OF SYNCHRONOUS Permanent Magnet Drives in FluX-Weakening Mode
}

\author{
Emmanuel HoAng, Mohamed Gabsi, Michel LÉcrivain, Bernard Multon* \\ LESiR - Ecole Normale Supérieure de Cachan, URA CNRS 1375, Cachan FRANCE \\ * Brittany Branch Campus of ENS de Cachan, located in Bruz, France \\ Phone number : (33) 147402111
}

Fax number : (33) 147402199

E-mail: emmanuel.hoang@lesir.ens-cachan.fr

\begin{abstract}
The aim of this paper is to present the structure of a new synchronous machine with stator ferrite permanent magnets and a salient passive rotor (a robust and low-cost technology) which, when supplied with current by a threephase bridge converter, produces continuous torque. This feature serves to place our machine on a par with the best synchronous machines available (e.g. high-energy rotor magnets with flux concentration). Furthermore, the electrical characteristics of this machine make it possible to apply the well-known flux weakening technique, which enhances the performance of the entire energy-conversion system. In theory, an operating area at constant power with unlimited speed can be obtained merely by taking into account the ohmic tension drops in the coils. Experimental results demonstrate that taking both magnetic losses and windage losses into account is necessary in order to identify the maximum mechanical output power characteristics.
\end{abstract}

Keywords : Synchronous machine, Permanent magnet, flux switching, flux weakening, iron losses.

\section{Machine presentation}

In this paper, we present a new structure for a synchronous polyphased (three-phase) machine with a stator concentrated flux and permanent magnets. This particular structure uses the principles of both flux switching and flux concentration [1,2,3]. As shown in Fig. 1, an elementary magnetic cell serves to explain the operating principle of this machine. According to the position of the mobile part, the magnetic flux-linkage in the armature winding can be counted as either positive or negative, and is then alternative. From the elementary cell, we developed a prototype (see Fig. 2), in accordance with applicable design rules [10].

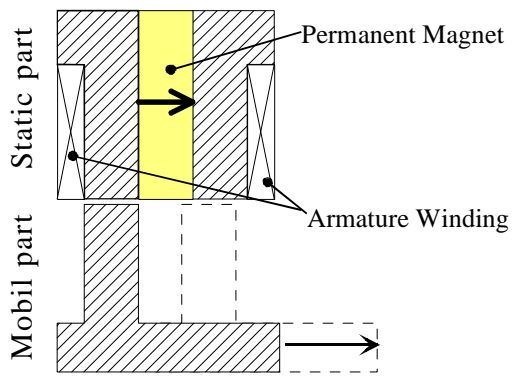

Fig.1.Elementary cell of the machine

This machine is composed of a stator that includes armature coils and permanent inductor magnets. The salient rotor is simply made of stacked soft-iron sheets. The prototype is a three-phase machine containing twelve magnets, with each phase thus comprising 4 magnets and 4 concentric coils. The rotor contains $\mathrm{N}_{\mathrm{r}}$ teeth (with $\mathrm{N}_{\mathrm{r}}=10$ ), and the relation between the mechanical rotation frequency $\mathbf{F}$ and the electrical frequency $\mathbf{f}$ can be expressed as: $\mathbf{f}=\mathbf{N}_{\mathbf{r}} \mathbf{F}$.

By virtue of its passive rotor, this machine displays highly-robust qualities; moreover, it is capable of attain- ing a high level of performance (specific torque and magnetic shear-stress). In association with a three-phase voltage bridge converter, this machine can work with a constant maximum power over a theoretically infinite range of speeds in the flux-weakening mode $[5,9]$.

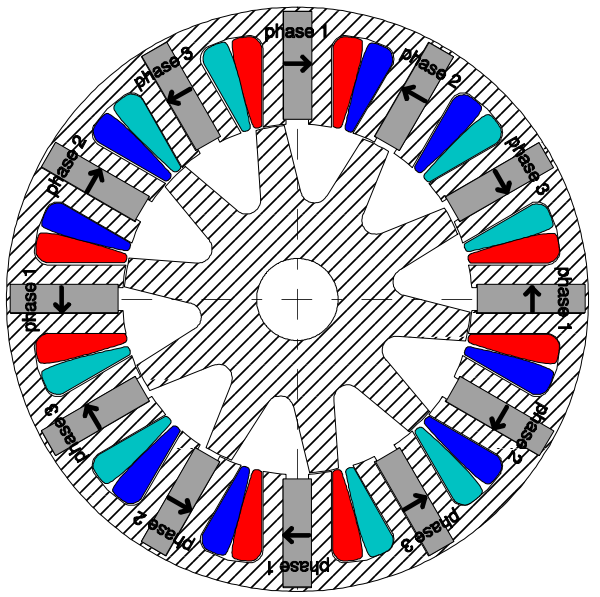

Fig. 2.Cross section of the three phases machine

A three-phase no-load flux (see Fig. 3), computed using a 2D Finite Element package [4], has enabled us to verify that the machine is indeed a balanced three-phase waveform with a sinusoidal flux (see Fig. 4: Measured EMF at 3,000 rpm).

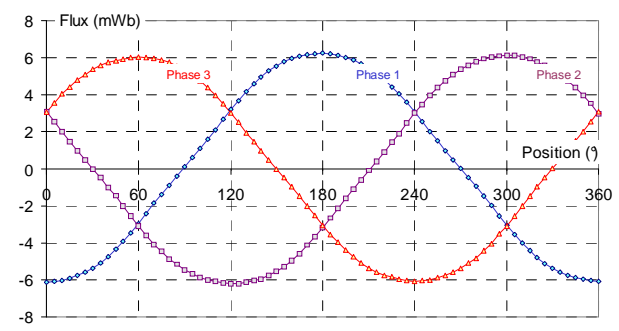

Fig.3.No-load flux (FE calculated) 


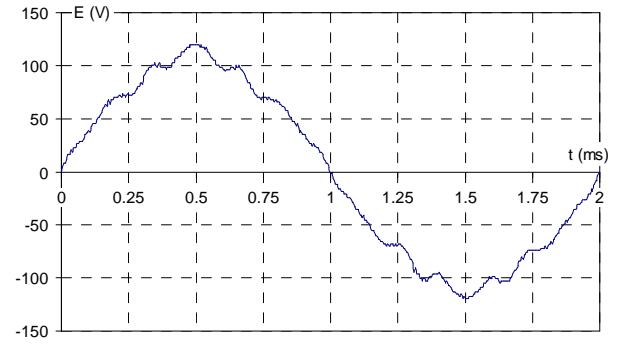

Fig.4.Measured EMF at 3,000 rpm

\section{Power capability}

\subsection{Presentation}

In this section, our main focus lies in the energyconversion possibilities of the machine when associated with a regulated current power converter. The operating principle has been diagrammed in Figure 5.

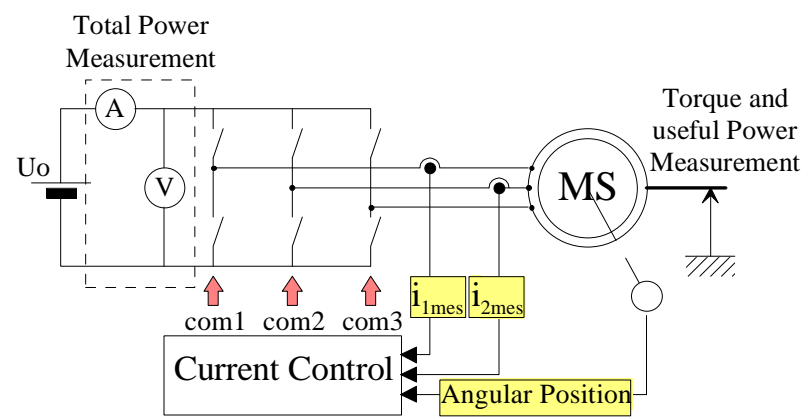

Fig.5.Diagram of current regulated - machine drive

In particular, we have examined the machine's power capabilities with respect to the voltage converter (Uo). This study incorporates the limited voltage of the DC source or the breakdown voltage of the transistors, as well as the machine's constraints (global machine heat, i.e. efficient current limitation at lower speeds).

Currents are controlled with the help of hysteresis comparators, with the regulation technique diagrammed below in Figure 6 :

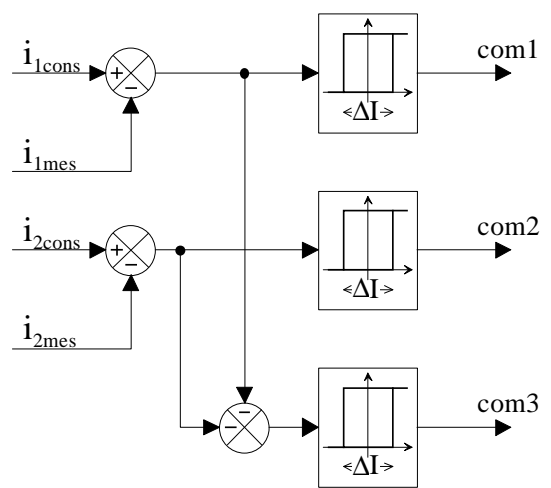

Fig.6.Current control by hysteresis regulator

At low speeds, the current is well-regulated (see Fig. 7); however, at high speeds, we apply the maximum voltage and the current is limited by both the EMF and the machine's impedances (see Fig. 8).

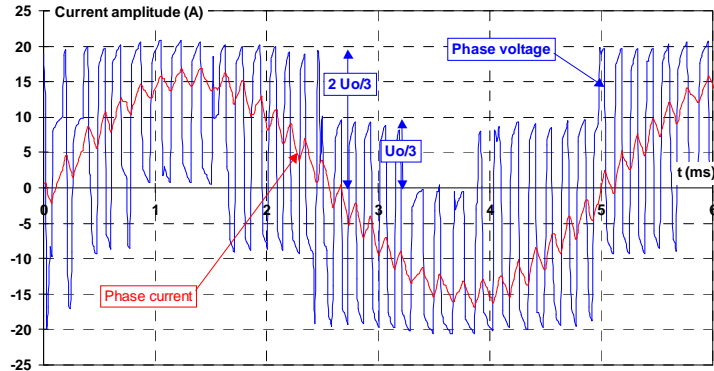

Fig.7. Experimental voltage and current at low speed

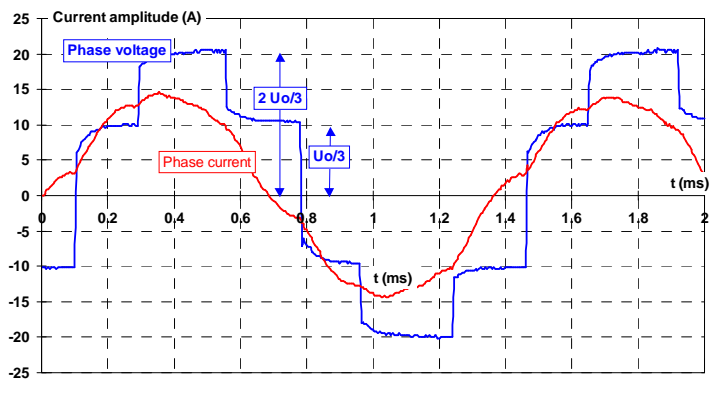

Fig.8. Experimental voltage and current at high speed

\subsection{Torque calculated using $d-q$ axis theory}

Using the classical d-q axis theory, we have determined the components of current which yield constant power capabilities up to an infinite speed (with losses being neglected, except for copper losses).

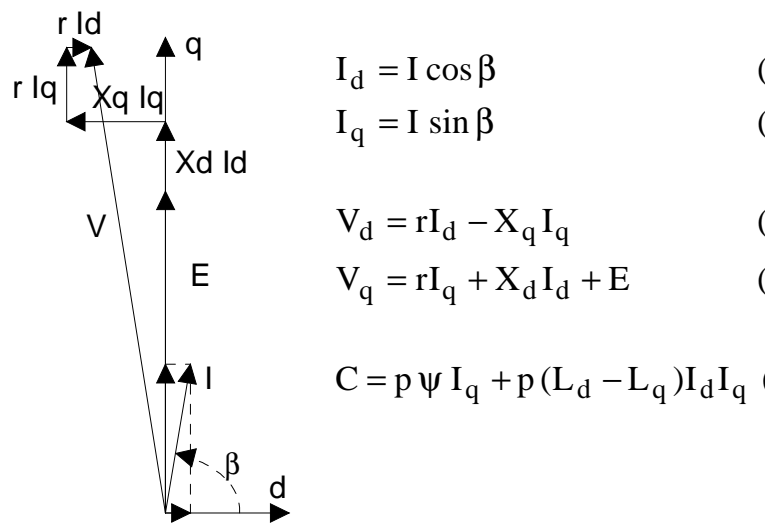

\subsection{Power capability at low speeds}

In this section, we present the machine's potential for energy conversion at low speeds. For this purpose, the constraints are thermal in nature. Since a thermal model is difficult to derive initially (with respect to determining the "copper-iron" thermal resistance), we have elected to perform calculations with a current density of $5 \mathrm{~A} / \mathrm{mm}^{2}$. For the prototype, in order to obtain this current density, the current amplitude must be equal to 18.3 A. The experimental specific torque is $1.54 \mathbf{~ N m} / \mathbf{k g}$ and the airgap magnetic shear-stress value is $\mathbf{1 . 2} \mathrm{N} / \mathbf{c m}^{2}$.

\subsection{Power capability at high speeds}

This machine does in fact exhibit a very high "flux weakening" capacity. The " $\mathrm{L}_{\mathrm{d}} \mathrm{I} / \psi$ " ratio is higher than " 1 ", for a current density of $5 \mathrm{~A} / \mathrm{mm}^{2}$, where $\mathrm{L}_{\mathrm{d}}$ is the $\mathrm{d}$-axis inductance, I the rated current and $\psi$ the d-axis magnetic flux-linkage. As observed in figure 9, three operating ranges can be detected, as follows : 
(1) At low speeds $(\mathrm{N}<2000 \mathrm{rpm})$, the torque is maximum, the current is limited $\left(I=I_{n}\right)$ and the current angle ( $\beta \approx 72^{\circ}$ ) is optimal for maximum torque.

2 For higher speeds than the rated speed $(\mathrm{N}=2000$ $\mathrm{rpm})$, the maximum torque is obtain with the limited current and with increasing current angle above $90^{\circ}(\beta$

$\boldsymbol{\gamma}$ and $\mathrm{I}=\mathrm{I}_{\mathrm{n}}$ ).

3 Beyond near the double rated speed ( $\mathrm{N}=4000 \mathrm{rpm})$, to have a maximum output power, the current angle must increasing but the current must decreasing under the limited current.

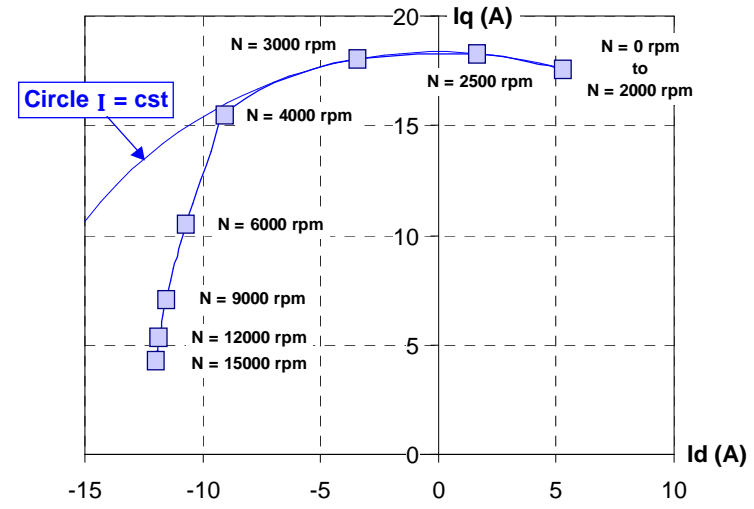

Fig.9.Current locus at maximum power

\section{Experimental results}

We have conducted experimental tests in order to determine the most effective torque and power for converting the machine with respect to its voltage converter. Measuring torque by means of a mechanical balance assembly, which exclusively targets the mechanical output torque, proves to be the best approach. Figure 12 presents both the experimental measurements and the set of computed points.

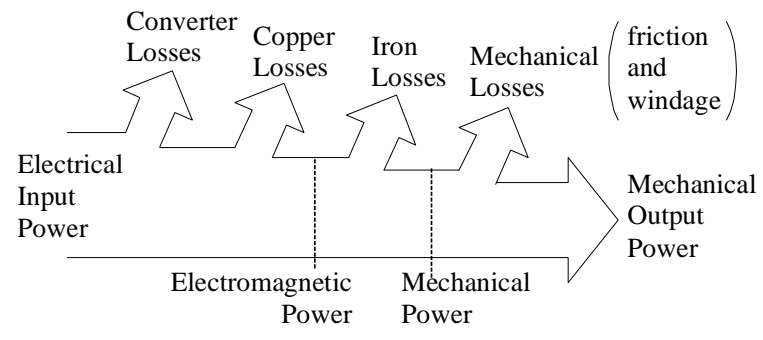

Fig.10. Evaluation of electrical and mechanical power

We can thereby measure:

- the input electrical power to the converter

- the losses in the converter (indirect measurement)

- the copper losses

- the output mechanical power.

We can estimate the ventilation losses thanks to [11] and the mechanical losses due to rolling (dry friction couple $\mathrm{C}_{0}=0.09 \mathrm{Nm}$ ).

This approach then allows us to deduce the iron losses.

To provide an order of magnitude of the various losses, we have presented them in Figure 11 as a function of the rotation speed at a power supply voltage of $300 \mathrm{~V}$.

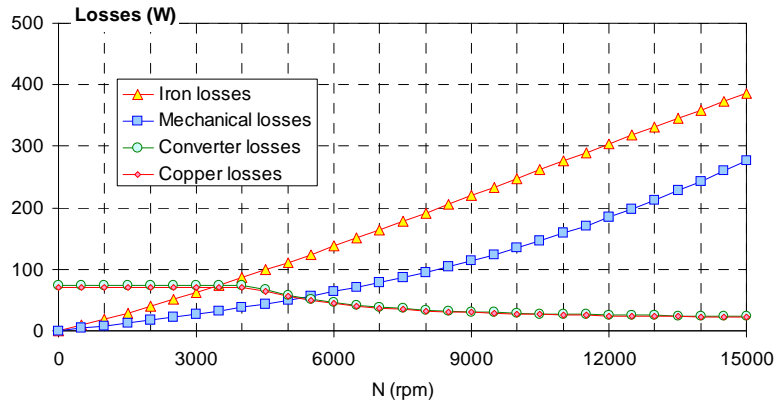

Fig.11. Evaluation of losses

In Figure 12, we have presented the various types of power of interest in our study. First is the electromagnetic power, which is what can be calculated using the classical d-q axis theory. Next comes the mechanical power, which is converted by the machine; this power is equal to the electromagnetic power less the iron losses. Lastly, the useful mechanical power is equal to the mechanical power less the mechanical losses intrinsic to the machine (losses in the bearings and ventilation losses).

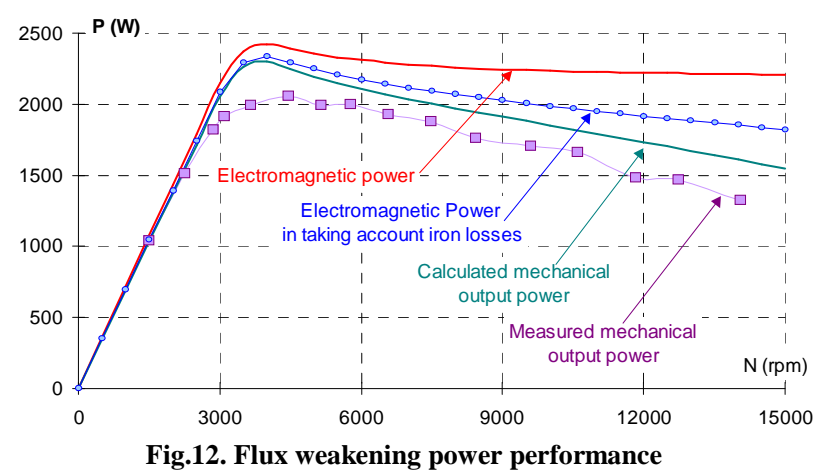

We can observe that when focusing on the potential for maximizing energy conversion, it is essential to include the losses occurring inside the magnetic circuit (iron losses). Moreover, it is also necessary to consider the mechanical losses, which however merely depend on the rotation speed and the structure of the rotor.

\section{Inclusion of losses}

In modelling both the magnetic losses and mechanical losses by means of a series resistor (see Fig. 13), which gets added to the winding resistance, it becomes possible to demonstrate that these losses are responsible for introducing a difference between the electromagnetic power and the converted power.

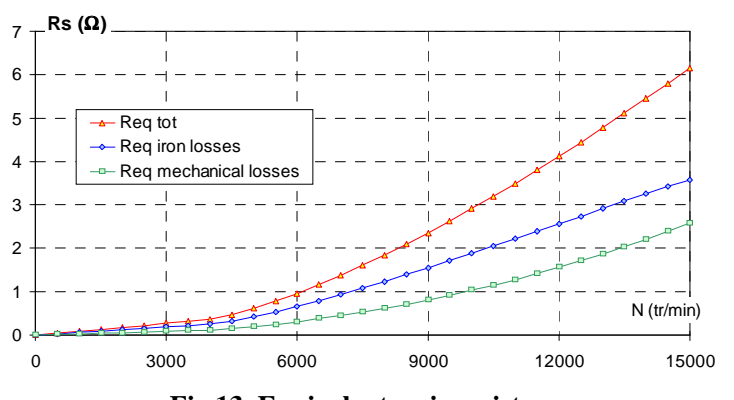

Fig.13. Equivalent serie resistor 


\section{Modelling of iron losses}

\subsection{Presentation of the model}

We have shown, from an experimental standpoint, the potential significance of iron losses within an overall evaluation of power. Our attention therefore turned to calculating these losses in order to develop a model based on the set of control parameters $(I, \beta, N)$. We applied the following classical calculation method:

(1) Determination of the flux density vector within the various zones of the machine, with the help of a 2D Finite Element package (see Figures 14 - 17).

This procedure was carried out for each of the operating points.

2 In each part, application of the following volumic iron loss model (in $\left.\mathrm{W} / \mathrm{m}^{3}\right)$ :

$\mathrm{p}_{\text {fer }}=\left(\mathrm{k}_{\mathrm{h} 1} \Delta \mathrm{B}+\mathrm{k}_{\mathrm{h} 2} \Delta \mathrm{B}^{2}\right) \mathrm{f}+\alpha_{\mathrm{p}}\left[\frac{1}{2 \pi} \int_{0}^{2 \pi}\left(\frac{\mathrm{dB}}{\mathrm{d} \theta}\right)^{2} \mathrm{~d} \theta\right] \omega^{2}$

with $\Delta \mathrm{B}=\mathrm{B}_{\max }-\mathrm{B}_{\text {min }}$

$\theta$ : electrical angle and $\omega$ : electrical pulsation

For the magnetic steel used $(0.35 \mathrm{~mm})$ :

$$
\mathrm{k}_{\mathrm{h} 1}=5 \quad \mathrm{k}_{\mathrm{h} 2}=30 \quad \alpha_{\mathrm{p}}=0.04
$$

Example : $\mathrm{B}(\mathrm{t})=\mathrm{B}_{\mathrm{M}} \sin \omega \mathrm{t}$ and $\omega=2 \pi \mathrm{f}$

$\mathrm{p}_{\text {fer }\left(\mathrm{W} / \mathrm{m}^{3}\right)}=\left(2 \mathrm{k}_{\mathrm{h} 1} \mathrm{~B}_{\mathrm{M}}+4 \mathrm{k}_{\mathrm{h} 2} \mathrm{~B}_{\mathrm{M}}{ }^{2}\right) \mathrm{f}+\frac{\alpha_{\mathrm{p}}}{2} \mathrm{~B}_{\mathrm{M}}{ }^{2} \omega^{2}$

With a density of $7800 \mathrm{~kg} / \mathrm{m}^{3}$, we have :

$\mathrm{p}_{\text {fer }}=2.4 \mathrm{~W} / \mathrm{kg}$ for $\mathrm{B}_{\mathrm{M}}=1.5 \mathrm{~T}$ and $\mathrm{f}=50 \mathrm{~Hz}$

$\mathrm{p}_{\text {fer }}=22.9 \mathrm{~W} / \mathrm{kg}$ for $\mathrm{B}_{\mathrm{M}}=1 \mathrm{~T}$ and $\mathrm{f}=400 \mathrm{~Hz}$

3 Total iron losses calculation :

For the area ' $\mathrm{j}$ ', the flux density vector is :

$\mathrm{B}_{\mathrm{jx}}(\theta)$ et $\mathrm{B}_{\mathrm{jy}}(\theta)$.

$\Rightarrow \mathrm{p}_{\mathrm{j}}=\left(\mathrm{p}\left(\mathrm{B}_{\mathrm{jx}}\right)+\mathrm{p}\left(\mathrm{B}_{\mathrm{jy}}\right)\right) \mathrm{vol}_{\mathrm{j}}$

with $\operatorname{vol}_{j}=$ volume of the area ' $\mathrm{j}$ ",

$\Rightarrow \mathrm{p}_{\text {iron }}=\sum_{\mathrm{j}} \mathrm{p}_{\mathrm{j}}$

\subsection{Calculation of the machine's iron losses}

We determined the shape of the flux density inside the machine for three operating points.

Point $0: \mathrm{I}=0$

Point $1: \mathrm{I}=\mathrm{I}_{\mathrm{n}}$ and $\beta=90^{\circ}$

Point $2: I=I_{n}$ and $\beta=135^{\circ}$

Point $3: \mathrm{I}=\mathrm{I}_{\mathrm{n}}$ and $\beta=180^{\circ}$

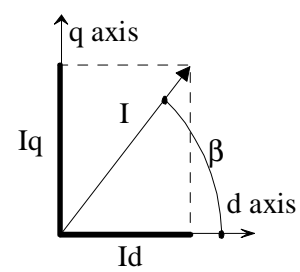

On the basis of the flux density values calculated, we then deduced the total iron losses for the machine.

Fig.18 displays the iron losses as a function of the angle " $\beta$ " calculated for three rotation speeds:

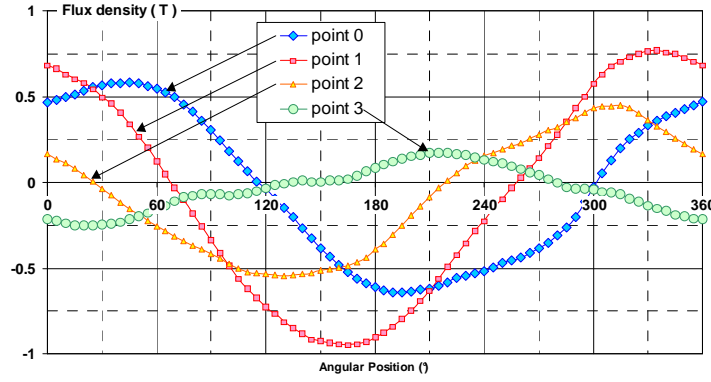

Fig.14. Flux density in stator yoke

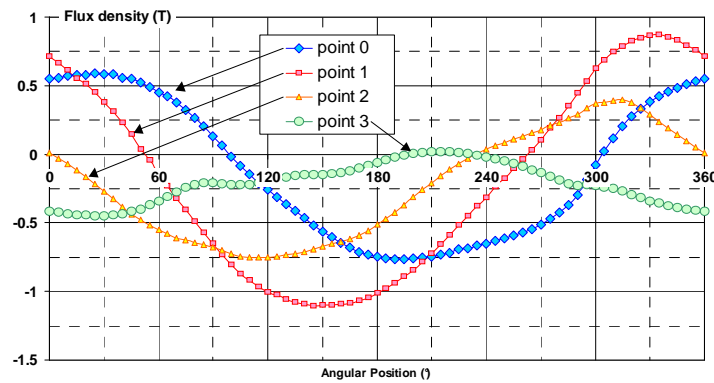

Fig.15. Flux density in stator teeth

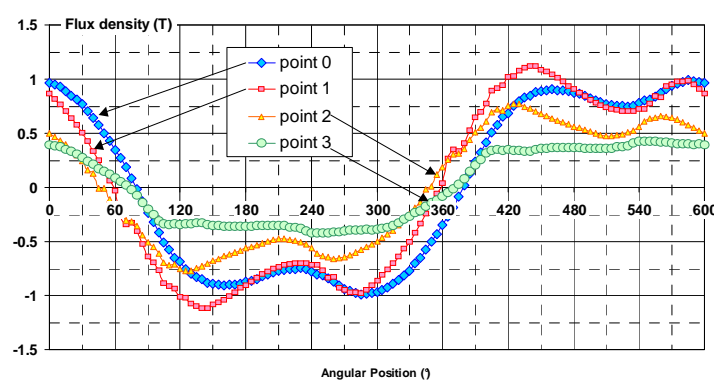

Fig.16. Flux density in rotor teeth

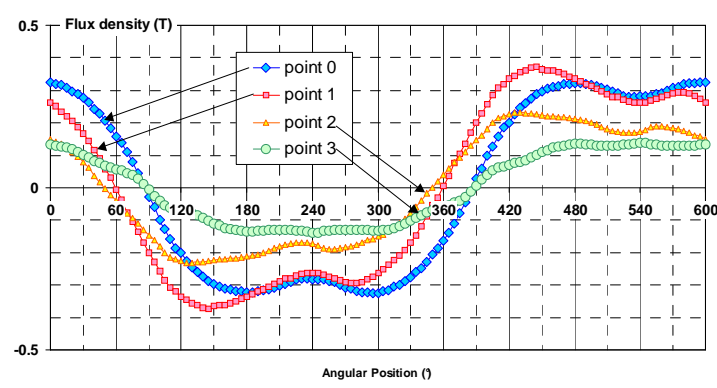

Fig.17. Flux density in rotor yoke

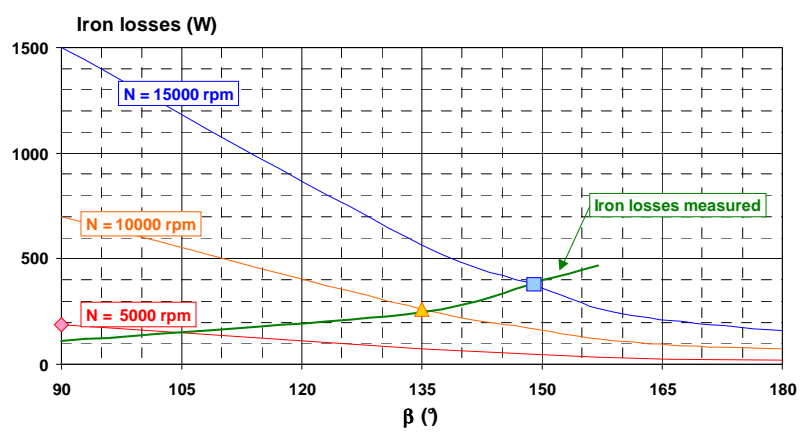

Fig.18. Iron losses calculated and measured

For the operating point at $10,000 \mathrm{rpm}$, the adjustment angle " $\beta$ " is equal to $135^{\circ}$; for $15,000 \mathrm{rpm}$, it equals $149^{\circ}$.

We then superimposed the iron losses measured with these three speeds and are in a position to state that a strong level of agreement has been reached between the measured and calculated values. 


\section{Conclusion}

This paper presents an original structure for a permanent magnet; synchronous polyphased machine based on the switching flux principle with a concentrated flux. The armature and inductor are both located inside the stator. The intrinsic performance obtained is most encouraging. We began by presenting the elementary cell and the switching flux principle. We then introduced a PM synchronous three-phase machine, along with its intrinsic characteristics. The performance measured using this revised configuration is equivalent, for the range of torque and speed examined, to the best machines currently available. The study conducted on a high-performance machine has revealed new possibilities for use with constant power and a theoretically-infinite range of speeds, in the case where copper losses are the only losses being taken into account. We have also shown that it is necessary to consider the machine's other intrinsic losses (friction and windage losses, magnetic losses) to be able to determine the speed-related characteristics of the maximum output convertible power. The iron losses can be predetermined with the help of a simple model, yet calculating the flux density vector requires the use of a Finite Element package. We have also observed that the adjustment angle " $\beta$ " exerts little influence on the value of the iron losses, whereas the current exerts a much stronger influence. It is therefore more efficient to operate the machine at high speeds and at currents close to the nominal current. It is possible to model both the iron losses and mechanical losses by means of series resistances; we will present a procedure for relating series resistances to these particular losses and then describe how the introduction of such a resistance modifies the machine model and the control parameters.

\section{Appendix}

Mechanical characteristics:

\begin{tabular}{|c|c||}
\hline External diameter & $143 \mathrm{~mm}$ \\
\hline Inner diameter & $86 \mathrm{~mm}$ \\
\hline Airgap length & $0.2 \mathrm{~mm}$ \\
\hline Active length & $60 \mathrm{~mm}$ \\
\hline Stator iron mass & $2.4 \mathrm{~kg}$ \\
\hline Rotor iron mass & $1.4 \mathrm{~kg}$ \\
\hline Copper mass & $1.1 \mathrm{~kg}$ \\
\hline Permanent magnet mass & $0.55 \mathrm{~kg}$ \\
\hline
\end{tabular}

Electrical characteristics:

\begin{tabular}{|c|c|}
\hline Flux linkage $(\psi)$ & $34 \mathrm{mWb}$ \\
\hline Rated current $(\mathrm{I}=\mathrm{In})$ & $18.3 \mathrm{~A}$ \\
\hline Phase resistance & $0.21 \Omega$ \\
\hline Inductance (d axis) & $\mathrm{L}_{\mathrm{d}}=3.6 \mathrm{mH}$ \\
\hline Inductance (q axis) & $\mathrm{L}_{\mathrm{q}}=2.7 \mathrm{mH}$ \\
\hline
\end{tabular}

\section{References}

[1] H. BEN AHMED

"Contribution to the permanent magnet machines with concentrated armature coils" (in French). PhD Thesis, 1994.

[2] L. PRÉVOND

"Study, modelisation and measurements of new linear and rotating hybrid actuators" (in French). PhD Thesis, 1994.

[3] D. AKEMEKOU

"Study, achievement and measurements of new hybrid motors (in French). PhD Thesis, 1996.

[4] MAXWELL software - ANSOFT CORPORATION

[5] W.L. SoOnG, Prof. T.J.E. MILLER

"Field-weakening performance of brushless synchronous AC motor drives".

IEE Proc.-Elect.Power Appl, Vol. 141, n 6, pp. 331-340, November 1994.

[6] T.M. JAHNS

"Flux-weakening regime operation of an interior permanent-magnet synchronous motor drive".

IEEE Trans. on Industry Applications, Vol. IA-231, n 4, pp. 681-689, July/August 1995.

[7] R.F. SCHIFERL, T.A. LIPO

"Power capability of salient pole permanent magnet synchronous motors in variable speed drive applications".

IEEE Trans. on IA, Vol. 26, n 1, pp. 115-122, January/February 1995.

[8] B.J. Chalmers, L. MusabA, D.F. Gosden

"Performance characteristics of synchronous motor drives with surface magnets and field weakening".

IEEE - IAS Conf., Vol. 1, pp. 511-517, 1996.

[9] B.J. Chalmers, L. MusabA, D.F. GOSDEN

"Variable-frequency synchronous motor drives for electric vehicles".

IEEE trans. On Industry Applications, Vol. 32, n²4, pp. 896-903, July/August 1996.

[10] E. HoAng, A.H. Ben AHMED, J. LuCIDARME

"Switching Flux Permanent Magnet Polyphased Synchronous Machines".

EPE-97 Conf., Trondheim, September 1997.

[11] James E. VRANCIK

"Prediction of Windage Power Loss in Alternators"

NASA technical note, TN D-4849, October 1968. 